\title{
Financing Enterprises to Boost Employment in Cameroon
}

\author{
Jean Marie Abega Ngono ${ }^{1}$, Célestin Chameni Nembua ${ }^{1} \&$ Moses Abit Ofeh ${ }^{2}$ \\ ${ }^{1} \mathrm{PhD}$ Student and Lecturer respectively, University of Yaounde II, Soa Cameroon \\ ${ }^{2}$ Department of Economics, Higher Teacher Training College Bambili, University of Bamenda, Cameroon \\ Correspondence: Moses A. Ofeh, Department of Economics, Higher Teacher Training College Bambili; \\ University of Bamenda, P.O BOX 39 Bambili, Cameroon. Tel: 237-677-879-520. E-mail: ofeh2002@ yahoo.fr
}

Received: August 4, 2019

Accepted: September 14, 2019

Online Published: September 25, 2019

doi:10.5539/ijef.v11n10p77

URL: https://doi.org/10.5539/ijef.v11n10p77

\begin{abstract}
Cameroon has 93969 different enterprises (NIS, 2010) operating in varied fields aimed at fostering economic growth. The enterprises confront challenges such as infrastructural weaknesses, unfavorable business climate and poor governance (World Bank, 2013), thus leading to disappointing results in terms of economic growth. Such a situation has attracted much attention from businessmen and policy-makers alike as to what to do in order to reverse the situation for favorable job creation and economic growth. The paper aims at examining the impact of external financing to enterprises in order to offer employment in Cameroon. Econometrically analyzing a sample of 180 loan recipients and 273 non-loan recipients, using the decomposition technique of Blinder-Oaxaca (1973), results show that enterprises that received external funding were more performing and creating jobs than those that did not, especially those operating in Yaoundé and Douala. A positive gap of total number of employees existed between loan and non-loan recipients estimated at 15 employees per enterprise. Also, such loans received positively amplify the actions of productive factors in Yaoundé and Douala considering the number of establishments and businesses. Equally, there exist a difference due to observable characteristics of enterprises and their coefficients, contributing 181.1 and $140.12 \%$ respectively for loan and non-loan recipients. We therefore recommend that the state, financial institutions and enterprises should work in synergy to collectively improve on enterprise financing so as to boost employment in Cameroon that can lead to economic growth.
\end{abstract}

Keywords: financing, enterprises, employment, Blinder-Oaxaca decomposition technique, Cameroon

\section{Introduction}

\subsection{Context of the Study}

For a long time and considering the framework of economic activities of nations, (Tamba, 1991; Louchart, 1995) enterprises play a fundamental role in the functioning, distribution and economic growth. In a specific way, the local private and multinational enterprises pushed by the search for profits, invest in new ideas and installations, reinforcing the base of economic growth and providing more than $90 \%$ of employment in the process of development of countries (World Bank, 2004). Cameroon has several enterprises operating in extremely varied fields. The General Census of Enterprises (GCE) in 2009 identified and located 93969 enterprises and establishments in business in Cameroon within the period (NIS, 2010).

According to the GCE of 2009, the entrepreneurial structure showed $75 \%$ of Very Small Enterprises, $19 \%$ of Small Enterprises, 5\% of Small and Medium size Enterprises and less than 1\% of Large Enterprises. The contribution of an enterprise in an economy is determined by the political, institutional and legal environment in which it operates (WB, 2004). A good climate of investment provides possibilities for enterprises to invest profitably, creating employments and increasing production, consequently increasing private investment and economic growth (Mbenda, 1989).

According to the definitions of International Labor Office, Michele Forte (2012), Arthelius (2016), Annie Fouquet $(2011,1998)$ and the economic and financial dictionary, employment is being defined as "an act which consists of contracting an activity with people able and available from the population on the basis of economic, social, and cultural aspects, giving right for remuneration". Since employment is one of the balances, according to MINEPAT (2014), it constitutes the principal form of social integration, a factor of improvement, and prevention of living conditions against the risks of poverty and vulnerability in Cameroon. 
However, the economic growth of Cameroon, despite the various efforts demonstrated remains disappointing due to infrastructural weaknesses, unfavorable business climate and poor governance (World Bank, 2013). The urgency to increase the dynamics of the Cameroonian enterprises becomes a fundamental element to reduce under- performance of the economic growth observed, as demonstrated by the low levels of execution of public and private investment plans, and the employability of human resources. A study of the socio-economic framework emphasizes an effective return of its economic growth since more than one decade, and states that its width remains insufficient (MINEPAT, 2014).

It arises from the GCE in 2009 that, Cameron's enterprises employed 386263 permanent employees (3.8\% of the working population) and 43495 non-permanent employees (NIS, 2010). A total of 429758 employments were recorded in all the firms, that is $4.3 \%$ of the working population estimated at nearly 10 million in 2009 . If the 196056 public agents were added, the total of the established positions amounted to 625814 , which is $6.2 \%$ being extremely low taking into consideration the working population (NIS, 2010). At the exit of the data-gathering of the annual investigation of enterprises in 2012, records revealed that permanent numbers were estimated at 460.000 in 2011 against 386.663 in 2009 . There were thus $4.6 \%$ of established positions in 2011 if the working population of 2009 remained unchanged. In 2013, at the request of MINEPAT, the NIS in collaboration with several other administrative and public institutions produced a relationship published by MINEPAT in 2014 on the creation of employment by the modern sector of the national economy between 2012 and 2013. From that situation, both public and private employment in the economy amounted to 990639 in 2013 as against 917639 in 2012. Thus, 9.9\% and 9.1\% of modern employment existed in 2013 and in 2012 respectively if the working population of 2009 remained the same.

By such records, there is evidence that a low capacity for absorption by Cameroon's enterprises, and generally by the modern sector, exist concerning employment creation. According to the preceding statistics, the National Institute of Statistics (2011) believes that the employment crisis is a very widespread phenomenon in Cameroon. Going by the National Fund of Employment (NFE), a secular arm of the Cameroonian State on employment promotion, the history of unemployment rates according to the view of ILO was $4.51 \%$ in $2016 ; 4.37 \%$ in 2015 ; $4.1 \%$ in 2014, 2013, 2012, 2011 and 2010; 3.51\% in 2009 and 3.21\% in 2008. However, it proves that unemployment rates published by the NFE are far from being identical to those of trade-union organizations. For proof, the NIS and trade-union organizations such as the Free Trade-Unions of Cameroon and the General Union of Cameroon Workers, are in disagreement over the unemployment rates in Cameroon. The NIS evaluates it to fall between $10 \%$ and $30 \%$, while FTUC and GUWC estimate it at approximately $70 \%$.

In this context, the employment crisis characterized by the importance of unemployment, under-employment and the preponderance of the informal sector support the prevalence of poverty in Cameroon. According to the forth Cameroon Household Survey (CHS) of 2014, 37.5\% of Cameroonians are poor. This investigation presents the evolution of the poverty line of $15.9 \%$ between 2001 and 2007, and of $26.1 \%$ between 2007 and 2014 attributing a weak purchasing power of Cameroonians. At these moments of overhauling, in the presence of employment crisis, of an increased unemployment and under employment, not only the efforts earmarked by the Government can solve the problem of socio- economic insertion of the working population. It is advisable to believe that, the activism of the operational structures following the sampled enterprises is an undeniable contribution in regard to the role that they play in the economy. Enterprises are reinforcement tools of all the economies and are essential sources of economic growth, dynamism and flexibility (Kasereka \& Kambala, 2013), in a prosperous business environment.

However, considering the difficulties that enterprises face in relation to their functioning, they can generally be disposed of by circumventing them via several financial means. On such basis, some studies (Lelart, 1991; Hugon, 1990) show that the internal financing cannot finance investments to a great extent. Thus, internal financing is a necessary but not however a sufficient condition for financing enterprises which have great needs for financing, as their investments exceed their saving capacities. Such weaknesses of internal financing imply recourse to imperative external financing.

\subsection{Aim of the Study}

Obviously, the financial function is incontestably the dominant function of the activities of enterprises and it would undoubtedly remain a long-term phenomenon because it is at the origin and the result of the majority of wealth creation processes for enterprises. With examples from Latin America, Asia and developed countries, banks as well as financial markets play a determining role in financing firms in the private sector, and are the engine of growth and employment creation (Kasereka \& Kambala, 2013). Without such institutions playing their roles fully, (Boccara, 2017) employment and a healthy economic growth would not be able to develop. 
Therefore, the study stipulates to examine the impact of external financing on boosting employment via enterprises in Cameroon. Specifically, it consists to study the relationship between external financing and the capacity of realizing productive investment enterprises; and to probe the impact of external financing on the capacities of enterprises to offer employment.1.3 Review of Related Literature

Some authors have showed a link between financial factors and employment offer by enterprises. According to Eggoh (2009), it is enough to imagine a world without the financial sector to realize its great task. So, Bekele and Workul (2008) thought that one of the causes of the premature suspension of activities by enterprises is the difficulty relating to financing. Also, Craig et al. (2007) showed that aside of some difficulties, the problem of access to financing is responsible for the closing down of most enterprises in sub-Saharan Africa. Such a problem remains most significant and would limit economic growth (Ngongang, 2012), and enterprises would be less employment offering.

In the neo-classical logic, enterprises offer the appropriate recruitment as long as the marginal productivities of the additional workers remain higher than their costs. According to Cahuc and Roux (2006) an enterprise has the interest to engage an employee as long as the additional receipt which the employee brings is higher than its average cost. Considering the capital factor, the worker by his labor force constitutes a factor whose value is socially determined and whose acquisition allows the enterprise to survive or to preserve its activities. Like a source of production, employment offer depends on labor cost and on the market power of enterprises. According to Keynes (1936), it depends on the productive level of the enterprise, and by Wadhawani (1986, 1987), Nickell and Wadhawani (1988, 1991) and Nickell and Nicolitsas (1999), financial factors are significant determinants of employment. Thus, we can also evoke the static theory of (Cahuc and Roux, 2006) and Rémi Bazillier for differences in terms of labor.

The static Theory of Employment Offer according to (Cahuc and Roux, 2006) and Rémi Bazillier: The ShortRun Context

In the labor market, the production function shows that employment offer is demonstrated as in the Cobb-Douglas function:

$$
Y=A L^{\alpha} K^{\beta}
$$

Where $Y$ is the firm's production, $L$ is labor input, $K$ being capital input and $A$ is technical progress.

With short-run hypothesis, only employment offer or labor input $(\mathrm{L})$ is flexible and the other factors for example capital are rigid. This employment offer depends on the real wage $w$ and market power, from where the production function and derivatives become:

$$
\begin{gathered}
Y=F(L) \\
\frac{\partial Y}{\partial L}=F^{\prime}(L)>0 \quad \text { and } \quad F^{\prime \prime}(L)<0
\end{gathered}
$$

Thus, the profit function of the enterprise appears as:

$$
\pi(L)=p(Y) Y-w L
$$

From where $w$ is labor cost and $p$ the price of a unit of good or service produced

The level of employment of the enterprise is chosen so that it maximizes its profit.

$$
\pi^{\prime}(L)=F^{\prime}(L)\left[p(Y)+p^{\prime}(Y) Y\right]-w=F^{\prime}(L) p(Y)\left[1+\eta_{Y}^{p}\right]-w=0
$$

Then, the second order condition is: $\pi^{\prime \prime}(L)=\left(1+\eta_{Y}^{p}\right)\left(F^{\prime 2} p^{\prime}+F^{\prime \prime} p\right)<0$

If the inequality above is checked, the employment offer is:

$$
F^{\prime}(L)=\gamma \frac{w}{p}
$$

Where $\gamma=\frac{1}{1+\eta_{Y}^{p}}$ is measurement of the margin which constitutes the market power of the enterprise.From here, the enterprise reaches its maximum profit when the marginal productivity of labor is equal to its $\operatorname{cost}\left(\frac{w}{p}\right)$ multiplied by the rate of margin. $F^{\prime}(L)$ is an increasing function in absolute value $\left|\eta_{Y}^{P}\right|$ of the price elasticity compared to production.

The cost function linked to the phenomenon of production leads to an analysis of the condition of optimality of equation (4). Here, with the lone factor of production, the cost function is not only linked to labor cost of 
producing quantity $Y$ of the good, i.e. $C(Y)=w L=F^{-1}(Y)$, where $F^{-1}$ indicates the reciprocal function of $F$, with $\left[F^{-1}\right]^{\prime}=1 / F^{\prime}$, then the marginal cost is:

$C^{\prime}(Y)={ }^{w} / F^{\prime}(L)$, and the relation (4) is written as:

$$
p=\gamma \frac{w}{F^{\prime}(L)}=\gamma C^{\prime}(Y)
$$

The price in the enterprise is fixed by multiplying the rate of the margin $(\gamma)$ by its marginal cost $C^{\prime}(Y)$. In pure and perfect competition $(\gamma=1)$, the price of a good is equal to its production cost. The influence of the variation of $w$ on the quantity of labor $(L)$ shows that:

$$
\frac{\partial L}{\partial w}=\gamma /\left(F^{\prime 2} p^{\prime}+F^{\prime \prime} p\right)<0
$$

In the short run, employment and supply level of goods are decreasing with respect to labor cost. Equally, the selling price of the good produced by the enterprise increases with $w$. It also arises that, with the rise in $\gamma$, employment opportunity and production level drop, while the price rises.

However, in the long run how does employment opportunity manifests in regard to other factors of the labor market?

\section{The Static Theory of Employment Offer according to (Cahuc \& Roux, 2006) and Rémi Bazillier: The Long-run Context}

In the long term, employment offer is characterized by the possibility of substitution and scale effects between labor and capital.

\section{Substitution Effects}

It is a question of considering $Y$ as being the representative level of production and searching for a function materialized by the entire optimal combination of production factors which allow for realizing $Y$. The cost function of the enterprise is:

$$
C(w, r, Y)=w L+r K
$$

Where $w$ and $r$ represent the remuneration of a unit of labor and capital respectively.

Thus, the function materializing the optimal combination of production factors results from the minimization of cost related to the realization of $Y$. That is to say:

$$
\left\{\begin{array}{l}
\min _{(K, L)}(w L+r K) \\
\mathrm{S} / \mathrm{C} F(K, L) \geq Y v
\end{array}\right.
$$

To solve this problem, requires fixing a conditional demand for labor $\bar{L}$ and of capital $\bar{K}$; the cost function of the enterprise becomes:

$$
C(w, r, Y)=w \bar{L}+r \bar{K}
$$

The application is derived from Shepherd compared to $w$ following the influence of the variation of the cost of a factor on the employment offer and provides the following equation (Kebewar, 2012):

$$
\frac{\partial \bar{L}}{\partial w}=C_{w w}(w, r, Y) \leq 0
$$

As in the neo-classical theory, employment opportunity decreases with real wage. The conditional demand for labor and capital depend on the cost ratio $w / r$. The conditional demand for labor decreases with $w$ and increases with $r$, that is to say, the more the wage $w$ increases, the less the enterprise offers employment, and also the more remuneration on the capital $r$ rises, the more the enterprise has preference to offer employment. On the other hand, the conditional demand for capital decreases with $r$ and increases with $w$. Therefore, the more the remuneration of capital $r$ increases, the less an enterprise gets external financings, and the more the wage $w$ rises, the more enterprises get the advantage of external financings.

The influence of a variation of cost of a factor on the employment offer depends on the proportion $(\beta)$ of labor factor cost in the total cost and of the elasticity of substitution between capital and labor $(\mu)$. That brings about the following relation:

$$
\bar{\eta}_{w}^{L}=-\bar{\eta}_{r}^{L}=-(1-\beta) \mu
$$

According this relation, as the influence of factor costs on the employment offer is raised, similarly its effect on elasticity of substitution of capital to labor $(\mu)$ too will be. In the same way, the elasticities (cross elasticity $\bar{\eta}_{r}^{L}$ and direct elasticity $\bar{\eta}_{w}^{L}$ ) of employment offer drop in absolute value with the share of cost of labor factor $(\beta)$ in the total cost, and conversely it rises with increase regarding cost of capital $(1-\beta)$ in the total cost. 
In regard to the problem, Hamermersh as in (Kebewar, 2012) showed that $\bar{\eta}_{r}^{L}$ and $\bar{\eta}_{w}^{L}$ represent substitution along only one isoquant and does not take into account the scale effect following the wage increase brought by that of production cost and this implies a rise in the cost of production and consequently a fall in the sale of goods. The scale effect observed is a function of the price elasticity of demand for products $(\eta)$, from where the form of the elasticity of employment offer as compared to the wage is as follows:

$$
\bar{\eta}_{w}^{L}=-(1-\beta) \mu-\beta \eta
$$

In the presence of the price elasticity of demand for products, the elasticity of the employment offers as compared to the wages $\left(\bar{\eta}_{w}^{L}\right)$ is higher if the price elasticity of demand for goods $(\eta)$ is large.

\section{Methodology}

\subsection{Source of Data}

Secondary data used was extracted from an investigative project "An analysis of the determinants of performance of enterprises in French-speaking sub-Saharan Africa: case of Cameroon, Ivory Coast and Senegal", sponsored by the Research Center for International Development. In Cameroon, the investigation had proceeded in the Center, Littoral and West regions, precisely in the towns of Yaounde, Douala and Bafoussam. The sample constituted of formal and informal production units of 72 formal enterprises in Yaounde, 280 in Douala and 28 in Bafoussam, and the informal production units (IPUs) were selected in the zones of strong concentration of informal activities randomly by the investigating body.

\subsection{The Modeling and Estimation Technique}

Available literature recommends several econometric models for the analysis of the effect of adoption of services. Some include, the linear multiple regression model, models of commutations "Switching regression model" and the model of decomposition of Blinder -Oaxaca (Dilling - Hansen et al., 1999; and Manyong, 2007; Pycroft, 2008).

The linear multiple employment regression models prove to be inappropriate, they are unable to specify the sign of the impact of the adoption of financing concerning employment offer of enterprises. The "Switching regression model" seems also inappropriate, as it determines only the variation of the number of employee for each category of enterprise, thus considering two situations: an initial situation represented by the status of each enterprise and a situation in which each one of these enterprises is supposed to occupy a status opposed to its initial state.

As for the Blinder - Oaxaca decomposition model, not only will it evaluate the variation of the number of employee between the recipient and non-loan recipient enterprises, but also it explains its variation. This model was used for the first time by Blinder and Oaxaca (1973) to determine and explain the wage difference between women and men. The subjacent idea being of knowing what the women would gain if they were remunerated like the men and what the men would gain, if they were paid like the women.

Such a model is welcomed in our study because, it enables us to know by how much the variation in the number of employee for the enterprises due to internal financing if they had the same advantages and characteristics as enterprises with external or internal financing.

Again, several authors and in various fields have used the model to prove its soundness (Lachaud, 1995; Davia \& Hernang, 2004; Haliona \& Lesueur, 2007). Thus, all this buttress our choice for the Blinder - Oaxaca decomposition model, using least squares estimation with two stages (Sserunkuma, 2005; Edwin \& Master, 2005; Mugisha \& Diiro, 2010), technique of estimation of two stages of Heckman (Chevassus -Lozza \& Galliano, 2001; Ntsama, 2007; Narrow Part, 2008; Tiamiyu et al., 2009) or the control function (Mugisha \& Diiro, 2010) to correct skewness of endogeneity, of selectivity or both at the same time, in the event of their confirmation.

\subsection{The Functional Form}

Generally, in literature two principal functional approaches exist, the parametric and non-parametric. The parametric approach contains several functional forms of which the most applicable are: the Cobb-Douglas form (Edwin \& Master, 2005; Tiamiyu et al., 2009), the translog form (Ray, 1982; Hyuha et al., 2007) and the quadratic form (Shumway et al., 1988; Huffman \& Evenson, 1989).The non-parametric approach consists of functions without preset forms whose techniques of estimation are the analysis by the data envelopment analysis (Chavas \& Cox, 1998; Tauer, 1995; Coelli \& Rao, 2003) and analyzing it by the stochastic frontier method (Ali \& flinn, 1989; Kolawole, 2006; Oladeebo \& Fajuyigbe, 2007; Ska \& Lawal, 2009).

However, the non-parametric approach is often exposed to many criticisms (Amara \& Romain, 2000). With regard to DEA model, several limitations can be enumerated. From its primarily deterministic nature, it is not possible to render account of the random aspect of the analyzed phenomena. In addition, the fact that the approach hasn't any property prevents the realization of any test of assumption; and the technique also produces results very sensitive to 
extreme observations. With the stochastic frontier method, the problem of specification of the distribution of the error term is one of the limitations underlined in various studies. Consequently, the parametric approach precisely the Cobb-Douglas forms and translog are adopted. However, there is a nuance between the two. In fact, the translog form in its specification considers the cross effect of the variables if there exists, which is not the case for the Cobb-Douglas function. Nevertheless, we retained the linearized Cobb Douglas form and not the forced (Ntsama, 2007), because it has the advantage of facilitating the interpretation of results. By implication, the estimated coefficients have the merit of indicating the elasticity of the dependent and independent variables as well.

\subsection{The Econometric Model and Variables Retained}

\subsubsection{Specificity of the Model of Analysis of the Gap of the Number of Employees}

The analysis takes its sources of study from Dilling-Hansen et al. (1999), Neuman and Oaxaca (2004) and Pycroft (2008). The decomposition of gap of number of employees between the Non-Loan and the loan Recipient Enterprises for the realization of their investments is based on following equation:

$$
\overline{\text { tonuempl }}^{\text {REL }}-\overline{\text { tonuempl }}^{\text {NREL }}=\left(\bar{X}^{R E L}-\bar{X}^{\text {NREL }}\right) \hat{\beta}^{R E L}+\bar{X}^{R E L}\left(\hat{\beta}^{R E L}-\hat{\beta}^{\text {NREL }}\right)
$$

Where tonuempl $^{\mathrm{REL}}-\overline{\text { tonuempl }}^{\mathrm{NREL}}$ is the difference between the total number of average employee of loan and non-loan recipient enterprises, where $\left(\overline{\mathrm{X}}^{\mathrm{REL}}-\overline{\mathrm{X}}^{\mathrm{NREL}}\right) \hat{\beta}^{\mathrm{REL}}$ is the difference due to the observable characteristics of enterprises and $\bar{X}^{\mathrm{REL}}\left(\hat{\beta}^{\mathrm{REL}}-\widehat{\beta}^{\mathrm{NREL}}\right)$ the difference of total number of employee due to the coefficients of the enterprises. The decomposition is grounded on the system of equations resulting from the procedure in the following two steps:

$$
\left\{\begin{array}{l}
\text { OBTAINING A LOAN } \text { L }_{i}=Z_{i} \delta+\varepsilon_{i} \\
\text { tonuempl }_{i}^{R E L}=X_{i}^{R E L} \beta^{R E L}+\sigma_{\varepsilon}^{R E L} \theta_{i}^{R E L}+\mu_{i}^{R E L} \\
\text { tonuempl } l_{i}^{N R E L}=X_{i}^{N R E L} \beta^{N R E L}+\sigma_{\varepsilon}^{N R E L} \theta_{i}^{N R E L}+\mu_{i}^{N R E L}
\end{array}\right.
$$

Where tonuempli $\mathrm{l}_{\mathrm{i}}^{\mathrm{REL}}$ and tonuempl $\mathrm{l}_{\mathrm{i}}^{\mathrm{NREL}}$ respectively indicate the logarithms of total number of employees of the loan and non-loan recipient enterprises. $\mathrm{X}_{\mathrm{i}}$ stands for a vector of explanatory variables likely to influence the employment offer of an enterprise. It is the same for both the REL the NREL. Its contents can be categorized into two types of variables: - Socio-economic variables of an enterprise including age, type, formality, activity sector, and town of implantation of enterprises.

- Inputs involve number of businesses, establishments handled by an enterprise, the educational level of manager and sex. $Z_{i}$ represents a vector of explanatory variables for obtaining a loan from a financial organization. Therefore $Z_{i}$ is a vector of socio-economic variables of the enterprise and inputs usage.

$\varepsilon_{\mathrm{i}}, \mu_{\mathrm{i}}^{\mathrm{REL}}$ and $\mu_{\mathrm{i}}^{\mathrm{NREL}}$ are the error terms respectively indicating the equations of the demand for loan, number of employee of loan and the non- loan recipient enterprises. $\sigma_{\varepsilon}^{\mathrm{REL}}$ and $\sigma_{\varepsilon}^{\mathrm{NREL}}$ are co-variances and are expressed as: $\operatorname{cov}\left(\mu^{\mathrm{REL}}, \varepsilon\right)=\sigma_{\varepsilon}^{\mathrm{REL}}$ andcov $\left(\mu^{\mathrm{NREL}}, \epsilon\right)=\sigma_{\varepsilon}^{\mathrm{NREL}}$.

Lastly, $\delta, \beta^{\mathrm{REL}}$ and $\beta^{\mathrm{NREL}}$ are coefficients measuring the relative contributions of the explanatory variables associated with them. However, it should be noted that the correction of the skewness of selection (if it exists) will be considered during the execution of the estimations of equations of number of employees. From here there is justification for two explanatory components in the equation of the decomposition of the variation of number of employee instead of three.

\subsubsection{The Variables of the Model}

\section{The Dependent Variable:}

- Number of employees: This is a quantitative variable made up of total number of permanent and non-permanent employees in 2012 taken for the load of enterprise $\mathrm{i}$.

\section{The Independent Variables}

- Socio-economic variables of enterprises:

- Age of the enterprise: it is a quantitative variable indicating the number of years of existence. The high age of an enterprise is synonymous to perennial and extended activities of the enterprise and consequently offering employment in such an activity;

- Type of enterprise: this variable is important because it influences employment offer, informs about nature of enterprise and could be multinomial with: $1=\mathrm{VSE}, 2=\mathrm{SE}, 3=\mathrm{ME}$ and $4=\mathrm{LE}$;

- Formality of the enterprise is another variable that influence employment offers. Taking into consideration its 
transparency, and contrary to an informal enterprise, the formal enterprise will be more solicited by the employment applicants thus could be binomial with: $1=$ Formal and $2=$ Informal;

- Activity sector: the activity sector includes a whole branch of categorized activities that create wealth giving the enterprises the possibility to offer employment. The variable is multinomial with: 1 = Primary, $2=$ Secondary and $3=$ Tertiary;

-Location town of enterprise: It is a qualitative variable indicating the town where the enterprise carries out its activities and it influences employment offer. It is multinomial in nature with: $1=$ Bafoussam, 2 = Douala and 3 = Yaounde.

- Input endowments of enterprises:

- Number of businesses is a continuous variable and expressed in millions of francs CFA. A high number of business affairs is synonymous to increased sales, the realization of several activities and a wide field of investigation which requires an employment offer for the control and execution of related tasks;

- Number of establishments handled by the enterprise is a quantitative variable and pointer of the number of stores, shops or subsidiaries which the enterprise has. The more an enterprise owes several establishments, the more it offers employment. This variable is positively correlated with the employment offer of enterprises;

- Educational level of the manager is an important variable as education is an investment which increases productivity of the enterprise. The responses about the educational level were categorized as: 1) Without level; 2) CEP/CEPE/FSLC; 3) BEPC/CAP/GCE 0L; 4) Probatory; 5) Bac / GCE Al; 6) BTS or equivalent; 7) License; 8) DEA, Master, Doctorate or more. At the end of analysis, we arranged the guarantors into four categories: Primary and without level having the guarantors 1 and 2; Secondary level with guarantors 3, 4 and 5; First cycle university with guarantors 6 and 7; and The last two academic cycles and more having the guarantor 8;

- Sex of the manager as a variable indicated the gender of the manager of an enterprise and was a binomial with: $1=$ Male and $2=$ Female.

\section{Results}

\subsection{Descriptive Analytical Results}

The analysis of table 1 show the different attributes and characteristics of enterprises.

- Age of the enterprise varies from 1 to 66 years with a mean of 10.81 years. By the results, most enterprises of the sample were recently created as their ages felt between 1 year and 10 years.

-By the type of enterprise, the sample indicated four types: Very small enterprises accounting for $66.70 \%$ (341 enterprises); Small enterprises accounting for $12.90 \%$ (68 enterprises); Medium-sized enterprises occupying a weight of $7.59 \%$ (40 enterprises); and Large enterprises accounting for $14.80 \%$ (70 enterprises). Statistically and averagely, it arises that the sample is not so far from the reality of the entrepreneurial structure in Cameroon.

- According to town of establishment, $12.14 \%$ or 64 enterprises were stablished in Bafoussam; $63.37 \%$ or 334 enterprises in Douala; and $24.47 \%$ or 129 enterprises in Yaoundé.

- Concerning the activity sector, three traditional activity sectors namely; the primary accounting for $1.32 \%$ or 7 enterprises, secondary accounting for $28.84 \%$ or 152 enterprises; and tertiary accounting for $69.82 \%$ or 368 enterprises.

- Distribution of enterprises according to formality shows that $27.89 \%$ or 147 enterprises carry out their activities in the formal while $72.11 \%$ or 380 enterprises perform in the informal sector. It is noted that nearly three quarter of the enterprises of the sample were not recorded in the trade register and the loans on personal property. In this regard, it is an indication of non- moral personality.

- The sample showed that the total number of businesses in 2012 recorded sale turnover varying between 2484 909 and 19592220 FCFA, with an average of 9891997 FCFA which is an indication that a majority of the enterprises in the sample are large.

- The sample also showed that the number of establishments per enterprise varied between 0 and 5.46, with a mean of 0.28 . This presents a real picture of the enterprises in the sample otherwise showing that enterprises have other establishments apart from the mother enterprises

- Averagely the educational level in the sample exhibits a higher tendency of $47.61 \%$ or 240 managers who have secondary level, $33.52 \%$ or 160 managers with higher level, and $66.48 \%$ or 358 managers of lower level of 
studies.

- The sample gives a gender management of enterprises to the tune of $71 \%$, or 358 enterprises managed by men and the rest by women.

Table 1. Descriptive statistics of the variables

\begin{tabular}{|c|c|c|c|c|c|c|}
\hline Variables & & Observation & Mean & Std. Dev. & Min & $\operatorname{Max}$ \\
\hline \multicolumn{7}{|l|}{ Qualitative variables } \\
\hline \multirow[t]{4}{*}{ Age of entreprise } & $1=1-10$ & 350 & .66 & .47 & 0 & 1 \\
\hline & $2=11-20$ & 108 & .20 & .40 & 0 & 1 \\
\hline & $3=21-30$ & 39 & .07 & .26 & 0 & 1 \\
\hline & $4=31$ and above & 30 & .06 & .23 & 0 & 1 \\
\hline \multirow[t]{4}{*}{ Types of enterprise } & $1=\mathrm{VSE}$ & 341 & .65 & .48 & 0 & 1 \\
\hline & $2=\mathrm{SE}$ & 68 & .13 & .34 & 0 & 1 \\
\hline & $3=\mathrm{ME}$ & 40 & .08 & .27 & 0 & 1 \\
\hline & $4=\mathrm{LE}$ & 70 & .15 & .36 & 0 & 1 \\
\hline \multirow[t]{3}{*}{ Activity sector } & $1=$ Primary & 7 & .01 & .11 & 0 & 1 \\
\hline & $2=$ Secondary & 152 & .29 & .45 & 0 & 1 \\
\hline & $3=$ Tertiary & 368 & .70 & .46 & 0 & 1 \\
\hline Format of the & $1=$ formal & 147 & .28 & .45 & 0 & 1 \\
\hline enterprise & $2=$ informal & 380 & .72 & .45 & 0 & 1 \\
\hline Town of & $1=$ Bafoussa & 64 & .12 & .33 & 0 & 1 \\
\hline establishment & $2=$ Douala & 334 & .63 & .48 & 0 & 1 \\
\hline of enterprise & 3 = Yaoundé & 129 & .24 & .43 & 0 & 1 \\
\hline \multirow[t]{6}{*}{ Level of study } & $1=$ no level & 12 & .02 & .15 & 0 & 1 \\
\hline & $2=$ Primary & 83 & .16 & .37 & 0 & 1 \\
\hline & 3 Secondary $1^{\mathrm{er}}$ Cycle & 174 & .35 & .48 & 0 & 1 \\
\hline & $4=$ Secondary $2^{\text {nde }}$ Cycle & 66 & .13 & .34 & 0 & 1 \\
\hline & $5=$ License & 79 & .16 & .36 & 0 & 1 \\
\hline & $6=$ Master and plus & 90 & .18 & .38 & 0 & 1 \\
\hline \multirow[t]{2}{*}{ Sex } & $1=$ men & 358 & .71 & .45 & 0 & 1 \\
\hline & $2=$ women & 146 & .29 & .45 & 0 & 1 \\
\hline \multicolumn{7}{|c|}{ Continuous variables and truncated variables with zero } \\
\hline $\begin{array}{l}\text { No. of establishments handled in } \\
2012\end{array}$ & No. of establishments per enterprise & 501 & .28 & .71 & 0 & 5.46 \\
\hline $\begin{array}{l}\text { Total no. of businesses realized in } \\
2012\end{array}$ & $\begin{array}{l}\text { Total no. of affairs in thousands of francs } \\
\text { CFA }\end{array}$ & 502 & 9.89 & 3.02 & 2.48 & 19.59 \\
\hline \multirow[t]{2}{*}{ Total no. of employees in 2012} & No. of permanent employees & 527 & 58.41 & 283.08 & 0 & 3960 \\
\hline & Non- permanent employees in 2012 & & & & & \\
\hline
\end{tabular}

Source: Calculations arrived at using Stata 14.0. and making useof Sample data.

A test of comparison of mean and variances (table 2) was conducted to compare the characteristics of the total number of employees taken in logarithm between the sampled enterprises, segmenting them according to loans and no-loans users (external financing). Nevertheless, the loan recipient enterprises had more employees than the non-recipients. The result was significant at $1 \%$ level of significance.

Table 2. Comparison test results of mean and variance of total number of employees of the enterprises

\begin{tabular}{|c|c|c|}
\hline \multirow[t]{2}{*}{ Variables } & \multicolumn{2}{|c|}{ Financial Source } \\
\hline & Receive at least a loan (External financing) & Did not receive a loan (Internal financing) \\
\hline No. of observations & 198 & 329 \\
\hline Mean & 2.83 & 0.94 \\
\hline Standard Deviation & $(1.5)$ & $(.07)$ \\
\hline Comparison of mean $\quad \mathrm{DL}=524$ & $\mathrm{P}_{\text {diff }<0}=.00$ & $P_{\text {diff }} \# 0=.00$ \\
\hline Comparison of variance DL $=328.19$ & $\mathrm{P}_{\text {ratio }}<1=.00$ & $\mathrm{P}_{\text {ratio\# } 0=.00}$ \\
\hline
\end{tabular}

Source: Calculations carried out with Stata 14.0, using sample data where t and $\mathrm{f}$ are respectively the Student and Fisher statistics.

\subsection{The Econometric Results}




\subsubsection{Tests of the Model: Test of Skewness of Selectivity and of Endogeneity}

The tests of existence of skewness of selectivity and endogeneity were conducted (see Appendix 1 and 2). The results obtained using Heckman showed that there was no skewness of selection for the two modes of equations. The Heckman test of the models appeared significant for the equations of the loan and non-loan recipients at $1 \%$ level of significance each. This could have been due to the fact that the coefficients of the terms of selection or the opposite of the ratio of Mills are statistically equal to zero. In addition, the test of increased regression or test of Hausman-Wu-Durbin made it possible to note that there was no risk of endogeneity. In that case, the coefficient of the residual of the estimate of the equation of adoption was statistically equal to zero with $\mathrm{F}$ (1, 432) $=.00$ and Prob $>F=.102$.

\subsubsection{Interpretation of the Estimation of Equations of Total Number of Employees}

Interpretation was made for the quality of contribution of variables (table 3 ) on the total number of employees of loan recipient enterprises (column 1). It therefore arises that:

- There exist a positive relationship between number of establishments handled by enterprises and total number of employee of enterprises. The is explained by the fact that, each additional enterprise (shop, store, etc.) expresses its wish to offer employment. Therefore, as an additional enterprise has subsidiary enterprises, the more it offers employment. Thus, the creation of an additional establishment by one mother enterprise increases by $21.10 \%$ the total number of employees for the loan recipient enterprises.

- There is equally a positive relationship between the number of businesses and the total number of employees of enterprises. The number of businesses is recognized as the first indicator of sale performance of an enterprise and which allows the enterprise to offer employment. This means that an increase of $1 \%$ of the sale turnover increases by $23.25 \%$ the total number of employees for the loan recipient enterprises.

- There exists a positive relationship between the town of installation of enterprise and the total number of employees of loan recipient enterprises. As such, the more a city accommodates activities and installation of enterprises, the more it offers employment. From the estimation on average, enterprises in the towns of Yaounde and Douala are more employment offering than those of Bafoussam.

- Concerning the educational level of managers of loan recipient enterprises, the estimate shows that enterprises managed by managers having an educational level corresponding to first degree or its equivalent have more employees than those managed by managers without any educational level. On the other hand, enterprises managed by managers having first and second cycle of secondary level; and the master level and above were not basically different.

- Concerning the formality of loan recipient enterprises, the estimate shows that the informal enterprises have fewer employees than formal enterprises. This substantiates why the recourse to loans by informal enterprises negatively influence their employment offer as compared to formal enterprises.

Table 3. Estimation results of the equations of the total number of employees

\begin{tabular}{|c|c|c|}
\hline Variables & Column (1) & Column (2) \\
\hline & $\begin{array}{l}\text { Equation1: Receive at least a loan (external } \\
\text { financing) Dep }\end{array}$ & $\begin{array}{l}\text { Equation2: Did not receive loan (interna } \\
\text { financing) Dep }\end{array}$ \\
\hline & Var: Tonuemployeei & Var: TonuemployeeJ \\
\hline \multirow[t]{2}{*}{$\operatorname{Ln}$ (no. of establishments) } & .21 & .25 \\
\hline & $(.10)^{*}$ & $(.12)^{*}$ \\
\hline \multirow[t]{2}{*}{ Ln(no. of businesses) } & .23 & .12 \\
\hline & $(.06)^{* * * *}$ & $(.04)^{* *}$ \\
\hline \multicolumn{3}{|l|}{ Sex } \\
\hline \multirow[t]{2}{*}{2 =women } & -.14 & -.7 \\
\hline & $(.21)$ & $(.09)$ \\
\hline \multicolumn{3}{|l|}{ Town } \\
\hline \multirow[t]{2}{*}{ 2=Douala } & .62 & .20 \\
\hline & $(.25)^{*}$ & $(.17)$ \\
\hline \multirow[t]{2}{*}{$3=$ Yaoundé } & .80 & .69 \\
\hline & $(.28)^{* * *}$ & $(.18)^{* * *}$ \\
\hline
\end{tabular}

Educational level of manager 


\begin{tabular}{|c|c|c|}
\hline $2=$ Primary & $\begin{array}{l}.52 \\
(.58)\end{array}$ & $\begin{array}{l}.42 \\
(.29)\end{array}$ \\
\hline $3=$ Secondary $1^{\text {st }}$ Cycle & $\begin{array}{l}.59 \\
(.58)\end{array}$ & $\begin{array}{l}.34 \\
(.28)\end{array}$ \\
\hline $4=$ Secondary $2^{\text {nd }}$ Cycle & $\begin{array}{l}.97 \\
(.59)\end{array}$ & $\begin{array}{l}.56 \\
(.29) *\end{array}$ \\
\hline $5=$ License & $\begin{array}{l}.99 \\
(.58) *\end{array}$ & $\begin{array}{l}.37 \\
(.30)\end{array}$ \\
\hline 7=Master $\&$ above & $\begin{array}{l}.68 \\
(.57)\end{array}$ & $\begin{array}{l}.70 \\
(.33)^{*}\end{array}$ \\
\hline Format of enterprise & & \\
\hline $2=$ informal & $\begin{array}{l}-1.81 \\
(.37)^{* * *}\end{array}$ & $\begin{array}{l}1.16 \\
(.29)^{* * *}\end{array}$ \\
\hline Type of enterprise & & \\
\hline $2=$ Small & $\begin{array}{l}.15 \\
(.28)\end{array}$ & $\begin{array}{l}.42 \\
(.16) * *\end{array}$ \\
\hline $3=$ medium-sized & $\begin{array}{l}-.59 \\
(.38)\end{array}$ & $\begin{array}{l}.80 \\
(.37) *\end{array}$ \\
\hline 4=large & $\begin{array}{l}-.12 \\
(.44)\end{array}$ & $\begin{array}{l}1.37 \\
(.39)^{* *}\end{array}$ \\
\hline Age of firm in years & & \\
\hline $11-20$ & $\begin{array}{l}.54 \\
(.21)\end{array}$ & $\begin{array}{l}.10 \\
(.13)\end{array}$ \\
\hline $21-30$ & $\begin{array}{l}-.01 \\
(.31)\end{array}$ & $\begin{array}{l}-.06 \\
(.23)\end{array}$ \\
\hline $31 \&$ above & $\begin{array}{l}.43 \\
(.31)\end{array}$ & $\begin{array}{l}.05 \\
(.34)\end{array}$ \\
\hline Activity sector & & \\
\hline $2=$ secondary & $\begin{array}{l}-.10 \\
(.46)\end{array}$ & $\begin{array}{l}-.36 \\
(.73)\end{array}$ \\
\hline $3=$ tertiary & $\begin{array}{l}-.37 \\
(.46)\end{array}$ & $\begin{array}{l}-.88 \\
(.73)\end{array}$ \\
\hline Constant & $\begin{array}{l}-.40 \\
(1.07)\end{array}$ & $\begin{array}{l}.82 \\
(.92)\end{array}$ \\
\hline No. of observations & 180 & 273 \\
\hline R-squared & .78 & .72 \\
\hline AdjR-squared & .75 & .70 \\
\hline $\mathrm{F}(\mathrm{k}, \mathrm{n}-\mathrm{k}-1)$ & 29.49 & 34.06 \\
\hline Prob $>\mathrm{Chi}^{2}$ & .00 & .00 \\
\hline
\end{tabular}

Source: Calculations by Stata 14.0. using Sample data. The values in brackets represent standard deviations of the test and with *, ** and *** significance at $10 \%, 5 \%$, and $1 \%$ respectively. " $\mathrm{n}$ " and " $\mathrm{k}$ " indicate sample size and number of explanatory variables in the model (excluding the constant term) respectively.

\subsubsection{Results of the Decomposition of Oaxaca - Blinder (1973)}

From the decomposition results on table 4, the predicted values of the logarithms of total number of mean employees of loan recipient and non-loan recipient enterprises are of 2.859 and 0.940 respectively. There is a logarithmic difference of 1.918 employees per enterprise. Thus, on average the loan recipient enterprises offer three times more employment than the non-recipients. This success translates the idea that enterprises that receive external financing (loans) contribute to an improvement of $200 \%$ towards employment offer.

In addition, enterprises not profiting from loans have a constant relatively more significant than those profiting. This is seen by the negative value of $-121.9 \%$ portraying the disadvantages given in $\{\mathrm{U}\}$. The results reveal that the differences due to individual characteristics and coefficients associated with the variables explain respectively $181.9 \%$ and $140.1 \%$ (values mentioned in $\{\mathrm{E}\}$ and $\{\mathrm{C}\}$ ) the distance of total number of the mean employees between the loan and non-loan recipient enterprises.

By comparing the mean values of these characteristics, it arises that there is a strong difference between the two 
groups of enterprises. This can be observed through their strong global contribution to the explanation of the gap of the total number of employees, estimated at $181.9 \%$ as mentioned in (E). One of the immediate consequences of the strong difference of the employment offer comes on the one hand from the strong existing difference between the contribution of all the components $\{\mathrm{E}+\mathrm{C}+\mathrm{U}\}$ of the model, and on the other hand, the weak contribution of components of coefficients of explanatory variables $\{\mathrm{C}+\mathrm{U}\}$ (with constant terms) of $200.1 \%$ and $18.2 \%$, respectively.

In a strict sense, the gap observed is explained by the differences due to the characteristics of enterprises on the one hand and to the differences in variations of these characteristics on the other hand, with contributions estimated at $90.9 \%$ and $9 \%$ respectively. This being the case, if the non-loan recipient enterprises had the same characteristics as the recipients, their total number of employees would increase by $90.9 \%$. On the other hand, if one brought back the levels of capacities of individual characteristics of recipients to those of non-loan recipients, their total number of employees would decrease by $9 \%$. From here and according the results, there exists a gap of employment offer between the two groups.

This result reveals on average that loan recipients have 15 employees more than the non-loan recipient enterprises.

Table 4. Results of the decomposition of the gap of total number of employees

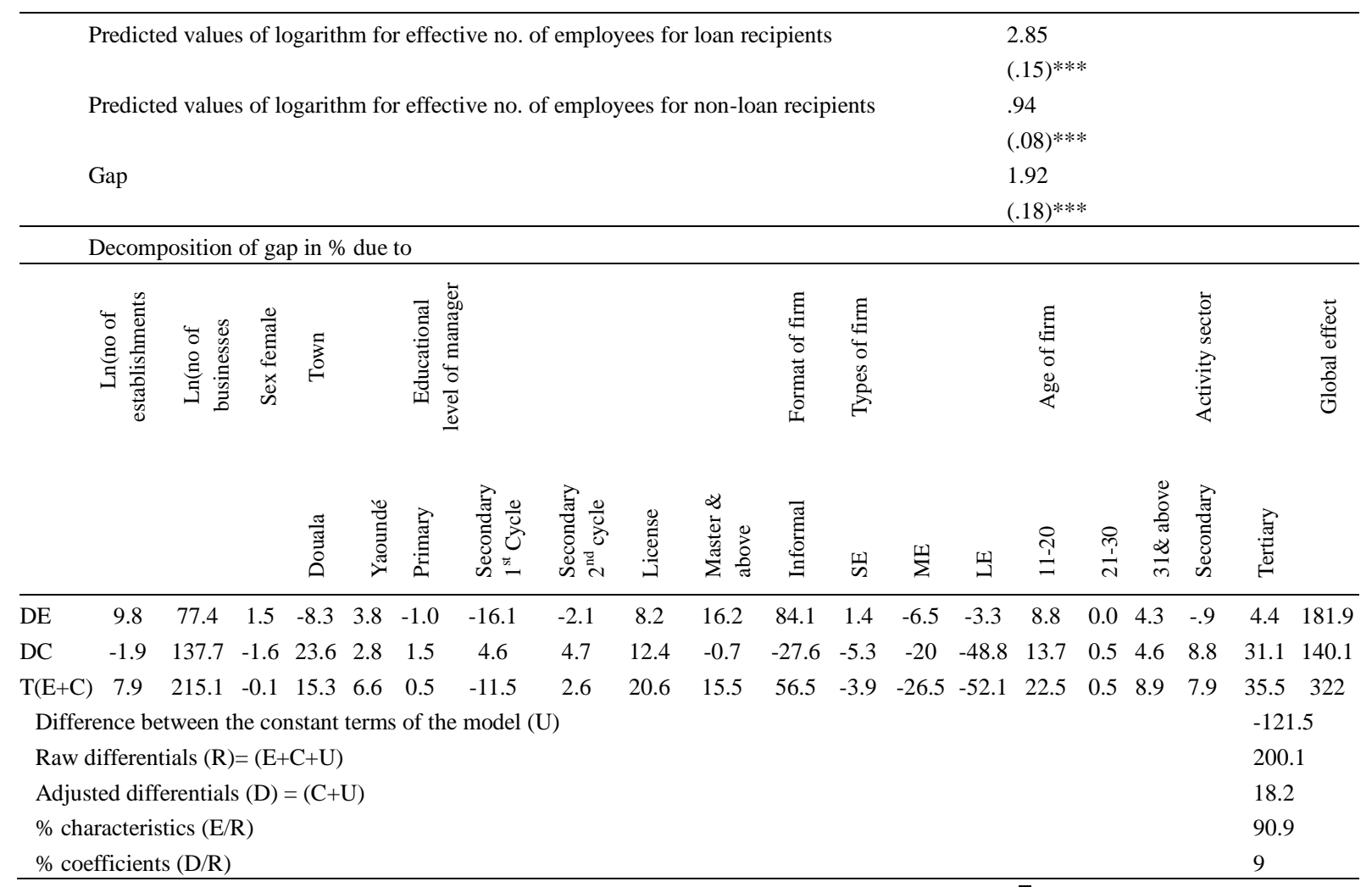

$\mathrm{DE}=$ Differences in characteristics $(\mathrm{E}), \mathrm{DC}=$ differences in coefficient associated variables $(\mathrm{C})$ and $\mathrm{T} \square(\mathrm{E}+\mathrm{C})=$ total effective aggregate differences $(\mathrm{E}+\mathrm{C})$.

Source: Construction by authors based on sample data. NB: The positive and negative values are respectively synonymous with advantages for the loan and non-loan recipients.

\section{Conclusion}

The paper stipulated to evaluate the impact of external financing of enterprises so as to boost employment in Cameroon. Statistically, the results obtained revealed that the test of comparison of the mean on average, indicated that the total number of employees of loan recipient enterprises is higher than those of non-loan recipients to the threshold of $1 \%$. Econometrically, the Blinder - Oaxaca decomposition showed that:

-The total number of employees between loan and non-loan recipient enterprises have a positive gap value estimated at 15 employees per enterprise. 
- A positive and significant role of loans granted by the financial donors show that there is a different in the total number of employees between recipients and non-loan recipients.

- Financial support from financial providers amplify the actions of factors positively through the number of establishments handled by enterprises, the number of businesses, the location towns of Yaounde and Douala, and the educational level attainment (first degree or its equivalent). However, this support is obstructed by the formality factor of enterprises (the informal modality).

- The differences due to characteristics and capacities of enterprises explain this positive gap, with contributions of $181.9 \%$ and $140.1 \%$ respectively.

From such results, we suggest that Cameroon should improve the access of VSE and SME to loans through credits, by economically and reasonably implementing prudential rules. These categories of enterprises constitute more than $97 \%$ of the totality of Cameroon entrepreneurship. The state must also, considering its kingly duty to framework, impose on financial institutions a scale of interest rates relating to different types of enterprises in order to encourage various investments. This is because some studies have showed that access to loans is very constraining.

-Financial institutions must start seriously collecting savings, transforming them into several financial products and to act resolutely to go out of persistent misunderstandings. They must leave the traditional ideology of bank functioning relating to bank loans which consists only in lending, easing availability of capital and interests related to debt. In this context, they must avoid that their contributions should not only play the role of shareholding in similar enterprises for their customers.

- Enterprises themselves must have a transparent, coherent and sustainable way of functioning. Therefore, enterprises having these qualities in their projects or investments will incite most financial institutions to finance their activities. Equally, they must have project solicitors, carriers, innovators, creators of wealth and in addition of having their own minimum capital stocks, perceived as an indicator of translating the authenticity and serenity of investments that can contribute to substantial employment and growth.

\section{References}

Annie, F.(1998). Travail, Emploi et Activité. Centre d'Etude de l'Emploi.

Blinder, A. S. (1973). Wage discrimination: Reduced forms and structural estimates. Journal of Human Resources, 8, 436-455. https://doi.org/10.2307/144855

Bruno, T. (2006). Karl Marx: L'organisation et l'exploitation du travail. In J. Allouche (Ed.), Encyclopédie des ressources humaines (2nd ed., pp. 1557-1564).

Cahuc, P., \& Roux, S. (2006). Cours Marche du travail et politiques d'emploi.

CDG 35 - Service Documentation / Conseil. (2011). La vacance ou la création d'un emploi permanent.

Chevassus-Lozza, E., \& Galliano, D. (2001). Les déterminants territoriaux de la compétitivité des firmes agro-alimentaires. Cahiers d'économie et sociologie rurales, $\mathrm{n}^{\circ} 58-59,30$ pages.

Coelli, T. J., \& PrasadaRao, D. S. (2003). Total Factor Productivity Growth in Agriculture: A Malmquist Index Analysis of 93 Countries, 1980-2000. CEPA.

Denis, D. (2000). Allocation des fonds propres en fonction du risque des actifs et impact sur le coût du capital.

Edwin, J., \& Masters, W. A. (2005). Genetic Improvement and Cocoa Yields in Ghana. Cambridge University Press, 41, 491-503. https://doi.org/10.1017/S0014479705002887

François, V. (n. d.). Marx et le travail: Acte créateur et instrument d'aliénation.

Funke, M., Maurer, W., \& Strulik, H. (1999). Capital structure and labor demand: investigations using German micro data. Oxford Bulletin of Economics \& Statistics, (61), 199-216. https://doi.org/10.1111/1468-0084.00125

Greene, W. H. (1981). Sample Selection Bias as a Specification Error: notes and comments. Econometrica, 49(3), 795-798. https://doi.org/10.2307/1911523

Halima, M. A., \& Lesueur, J. Y. (2007). Transition CDD - CDI et différentiels de salaire: Résultats économétriques sur l'enquête employ. UMR-CNRS, Document de Travail, ${ }^{\circ} 5824$.

Heckman, J. J. (1979). Sample Selection Bias as a Specification Error. Econometrica, 47(1), 153-161. https://doi.org/10.2307/1912352 
Huffman, W. E., \& Evenson, R. E. (1989). Supply and Demand Functions of Multiproduct US Cash Grain Farms: Biases Caused by Research and Other Policies. American Journal of Agricultural Economics, 71(3), 761-773. https://doi.org/10.2307/1242032

Hurlin, C. (2002). Econométrie des variables qualitatives. polycopié de cours, Université d'Orléans, p. 52.

Hyuha, T. S., Bashaasha, B., Nkonya, E., \& Kraybill, D. (2007). Analysis of Profit Inefficiency in Rice Production in Eastern and Northern Uganda. African Crop Science Journal, 15(4), 243-253.

John, M. K. (1936). Théorie générale de l'emploi, de l'intérêt et de la monnaie. Notice bibliographique pour la Bibliothèque de l'Encyclopaedia Universalis, Marion Gaspard, Triangle UMR 5206 et Université de Lyon.

Kamanzi, C. P. (2006). Influence du capital humain et du capital social sur les caractéristiques de l'emploi chez les diplômés postsecondaires au Canada.

Kasereka, M., \& Kambale, S. (2013). Problématique du financement des PME par les établissements bancaires en RDC: Cas de la ville de Butembo.

Kebewar, M. (2012). La structure du capital et son impact sur la profitabilité et sur la demande de travail: Analyses théoriques et empiriques sur données de panel françaises. Doctorat en Sciences Economiques soutenu à l'université d'Orléans.

Kolawole, O. (2006). Determinants of Profit Efficiency among Small Scale Rice Farmers in Nigeria. Research Journal of Applied Sciences, 1(1-4), 116-122. Retrieved from http://www.medwell.org

Michel, H. (1996). Les ajustements de l'emploi. Pour une critique de l'économétrie bourgeoise.

Minepat. (2014). Tendances sur la création d'emplois dans le secteur moderne de l'économie entre 2012 et 2013.

Mokhtar, L. (1999). Principes d'économie contemporaine.

Mugisha, J., \& Diiro, G. (2010). Explaining the Adoption of Improved Maize Varieties and its Effects on Yields among Smallholder Maize Farmers in Eastern and Central Uganda. Middle-East Journal of Scientific Research, 5(1), 06-13.

Nickell S. J., \& Wadhwani, S. (1991). Employment Determination in British Industry: Investigations Using Micro Data. Review of Economic Studies, (58), 955-69. https://doi.org/10.2307/2297946

Nickell, S. J., \& Wadhwani, S. (1988). Unions, Wages and Employment, Test Based on U.K. Firm-Level Data. European Economic Review, (32), 727-33. https://doi.org/10.1016/0014-2921(88)90221-8

Nickell, S., \& Nicolitsas, D. (1999). How does financial pressure affect firms? European Economic Review, (43), 1435-1456. https://doi.org/10.1016/S0014-2921(98)00049-X

Ntsama, E. S. M. (2007). Analyse de l'impact de l'innovation sur la productivité agricole: Cas du maïs dans la province du Centre-Cameroun. mémoire de DEA-PTCI, Université de Yaoundé II-Soa, Cameroun, p. 123.

Oaxaca, R. (1973). Male-female wage differentials in urban labor markets. International Economic Review, 14, 693-709. https://doi.org/10.2307/2525981

Oladeebo, J. O., \&Fajuyigbe, A. A. (2007). Technical Efficiency of Men and Women Upland Rice Farmers in

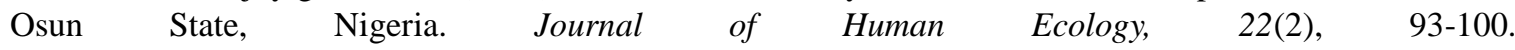
https://doi.org/10.1080/09709274.2007.11906006

Perroulaz, G. (2004). Le rôle des ONG dans la politique de développement: Forces et limites. Légitimité et Contrôle, 9-24.

Philippe, E. (1994). La conceptualisation de l'emploi: Approches macro-analytiques et problématique de la régulation juridique. Université Nancy 2 UFR de droit, Sciences Economiques et Gestion.

Plan d'Action National pour l'Emploi des Jeunes 2016-2020. (2015).

Pycroft, J. (2008). The Adoption and Productivity of Modern Agricultural Technologies in the Ethiopian Highlands: A cross-sectional analysis of maize production in the West Gojam zone. University of Sussex, 20 pages.

Ray, S. C. (1982). A translog Cost Function Analysis of US Agriculture, 1939-1977. American Journal of Agricultural Economics, 64(4), 490-498. https://doi.org/10.2307/1240641

Rémi, B. (n. d.). Chapitre 3: La demande de travail. Cours d'Economie du Travail L3 EG Orléans.

Shumway, C. R., Saez, R. R., \& Gottret, P. E. (1988). Multiproduct Supply and Input Demand in US Agriculture. 
American Journal of Agricultural Economics, 70(2), 330-337. https://doi.org/10.2307/1242073

Sserunkuma, D. (2005). The Adoption and Impact of Improved Maize and Land Management Technologies in Uganda. Electronic Journal of Agricultural and Development Economics, 2(1), 67-84.

Tauer, L. W. (1995). Do New York Dairy Farmers Maximise Profits or Minimise Costs? American Journal of Agricultural Economics, 77(2), 421-429. https://doi.org/10.2307/1243551

Tiamiyu, S. A., Akintola, J. O., \& Rahji, M. A. Y. (2009). Technology Adoption and Productivity Difference among Growers of New Rice for Africa in Savanna Zone of Nigeria. TROPICULTURA, 27(4), 193-197.

Wadhwani, S. (1987). The Effects of Inflation and Real Wages on Employment. Economica, (54), 21-40. https://doi.org/10.2307/2554341

Wooldridge, J. (2002). Econometric Analysis of Cross-Section and Panel Data. Massachusetts: The MIT Press.

\section{Appendix 1}

Table 1. Test of existence of skewness of selectivity

\begin{tabular}{|c|c|c|c|}
\hline \multirow[t]{5}{*}{ Variables } & \multicolumn{3}{|c|}{ Equations of total number of employment by group } \\
\hline & Column 1 & Column 2 & Column 3 \\
\hline & Equation1:receive at least a & Equation2:Did not receive a & Equation of obtaining a \\
\hline & loan & loan & loan \\
\hline & Dep.Var:Tonuempli & Dep.Var:tonuemplj & Dep.Var:obtaining loan \\
\hline \multirow[t]{2}{*}{$\operatorname{Ln}($ no. of establishment) } & .23 & .33 & .06 \\
\hline & $(.10)$ & $(.08)^{* * *}$ & $(.12)$ \\
\hline \multirow[t]{2}{*}{ Ln(no. of business) } & .14 & .15 & .22 \\
\hline & $(.03)^{* * * *}$ & $(.03)^{* * * *}$ & $(.06)^{* * * *}$ \\
\hline \multicolumn{4}{|l|}{ Sex } \\
\hline \multirow[t]{2}{*}{$2=$ Woman } & -.10 & -.12 & \\
\hline & $(.08)$ & $(.09)$ & \\
\hline \multicolumn{4}{|c|}{ Town } \\
\hline \multirow[t]{2}{*}{ 2= Douala } & .27 & .48 & \\
\hline & $(.14)^{*}$ & $(.14)^{* * *}$ & \\
\hline \multirow[t]{2}{*}{ 3= Yaounde } & .80 & .78 & \\
\hline & $(.15)^{* * *}$ & $(.15)^{* * *}$ & \\
\hline \multicolumn{4}{|c|}{ Education level of manager } \\
\hline \multirow[t]{2}{*}{ 1= Primary } & .29 & .35 & .31 \\
\hline & $(.26)$ & $(.27)$ & $(.49)$ \\
\hline \multirow[t]{2}{*}{$2=$ Secondary $1^{\text {st }}$ cycle } & .28 & .32 & -.13 \\
\hline & $(.25)$ & $(.26)$ & (.48) \\
\hline \multirow[t]{2}{*}{$3=$ Secondary $2^{\text {nd }}$ cycle } & .53 & .64 & .14 \\
\hline & $(.26)^{*}$ & $(.27)^{*}$ & $(.50)$ \\
\hline \multirow[t]{2}{*}{ 4= License } & .35 & .62 & .25 \\
\hline & $(.27)$ & $(? 27)$ & $(.49)$ \\
\hline \multirow[t]{2}{*}{ 5= Master \& above } & .58 & .46 & .13 \\
\hline & $(.29)^{*}$ & $(.28)$ & $(.50)$ \\
\hline \multicolumn{4}{|l|}{ Format of enterprise } \\
\hline \multirow[t]{2}{*}{$2=$ Informal } & -1.17 & -1.76 & -.29 \\
\hline & $(.27)^{* * *}$ & $(.24)^{* * *}$ & $(.34)$ \\
\hline \multicolumn{4}{|l|}{ Type of enterprise } \\
\hline \multirow[t]{2}{*}{$2=$ Small enterprise } & .33 & .39 & .58 \\
\hline & $(.14)^{*}$ & $(.14)^{* *}$ & $(.21)^{* *}$ \\
\hline \multirow[t]{2}{*}{ 3= Medium sized enterprise } & .57 & -.17 & .08 \\
\hline & $(.32)^{*}$ & $(.26)$ & $(.38)$ \\
\hline \multirow[t]{2}{*}{ 4= large enterprise } & 1.17 & .44 & -.35 \\
\hline & $(.35)^{* *}$ & $(.28)$ & $(.43)$ \\
\hline \multicolumn{4}{|l|}{ Age of enterprise in years } \\
\hline \multirow[t]{2}{*}{$11-20$} & .17 & .33 & .24 \\
\hline & $(.11)^{* *}$ & $(.11)^{* *}$ & $(.18)$ \\
\hline
\end{tabular}




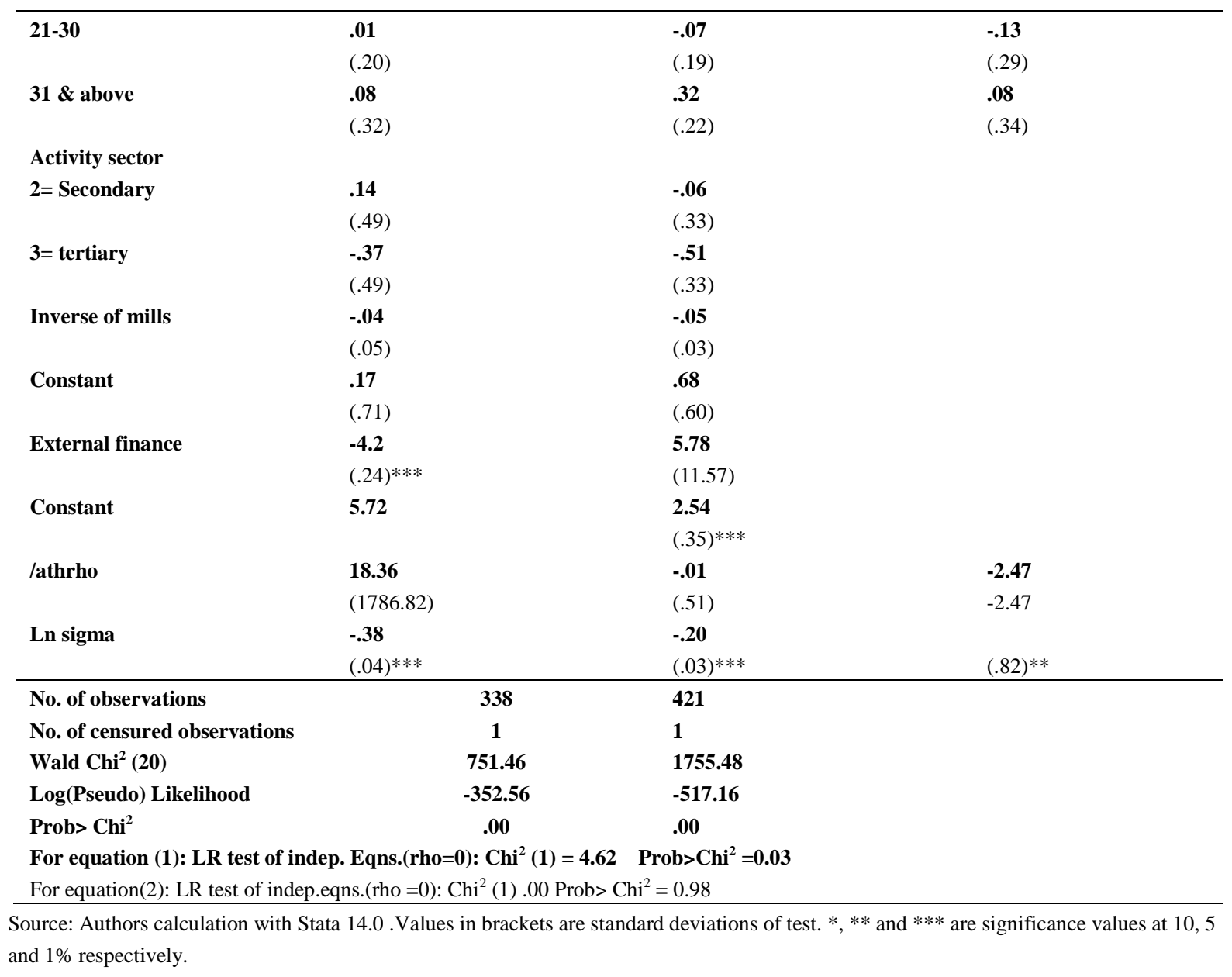

Appendix 2. Test of existence of skewness of endogeneity: Test of increased regression or test of Hausman-Wu-Durbin

Table 2. Test of existence of skews of endogeneity

\begin{tabular}{lc}
\hline Variables & Equation of total no. of employees \\
\hline Res.obtaining a loan & -4.12 \\
Ln(no. of business) & $(2.52)$ \\
Ln(no. of establishment) & .44 \\
Sex & $.17)^{* *}$ \\
2= female & .33 \\
Town & $(.14)^{*}$ \\
2=Douala & -.15 \\
3=Yaoundé & $.09)^{*}$ \\
Education level of Manager & .44 \\
1= Primary & $(.14)^{* *}$ \\
2= Secondary $1^{\text {st }}$ cycle & .79 \\
3= Secondary $2^{\text {nd }}$ cycle & $(.15)^{* * *}$ \\
& .68 \\
\hline
\end{tabular}




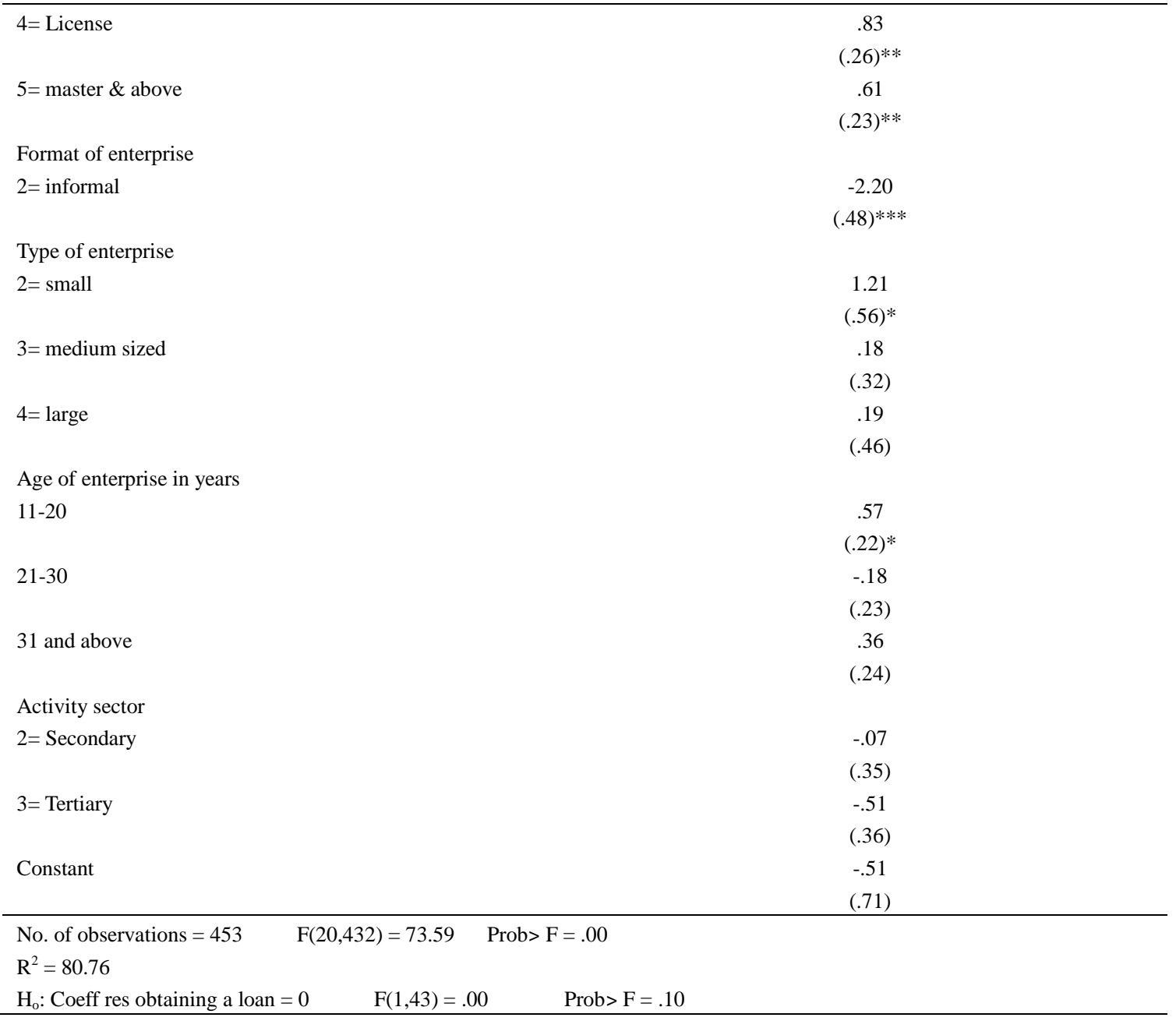

Source: Calculations of authors from Stata 14.0. Values in brackets represent standard deviations of the test. *,** and *** are significance at 10,5 and $1 \%$ respectively.

\section{Copyrights}

Copyright for this article is retained by the author(s), with first publication rights granted to the journal.

This is an open-access article distributed under the terms and conditions of the Creative Commons Attribution license (http://creativecommons.org/licenses/by/4.0/). 